\title{
The South African security predicament: making sense of the objective realities
}

\author{
Prof. Abel Esterhuyse ${ }^{1}$ \\ Stellenbosch University
}

\begin{abstract}
This article reflects an effort to make sense of the objective realities of the South African security predicament. The objective realities on the security agenda are rooted in the practical reality of experience and are open for public discussion, debate and speculation. These realities are informed by the threats facing South Africans on a daily basis. Government provides security with subjective content to the extent that political power demarcates the threat agenda, prioritises the items on the threat agenda, and foots the security bill. Since the creation of the Union in 1910, South Africa has had to find a balance between the security realities emanating from three key security domains - irrespective of the ruling entity: security threats from outside Africa, those threats facing the country from within Africa, and security threats from within the borders of South Africa. The article aims at a scholarly demarcation of some of the most critical, important, and key features of the South African security agenda using these three domains as a framework for discussion. On a secondary level, the discussion also critically reflects on the ability of the human security paradigm to address the South African security predicament.
\end{abstract}

\section{Introduction}

There seems to be a general agreement between those looking at South Africa from the outside, and those looking from inside the country, that South Africa faces a considerable security predicament. ${ }^{2}$ South Africa embraced a "powerful approach to security" 3 in the 1990s, depicted as human security; first popularised and outlined in the United Nations, Human Development Report 1994. ${ }^{4}$ However, the security situation in South Africa has deteriorated in recent times to the extent that the Minister of Police, $\mathrm{Mr}$ Bheki Cele, recently noted that, the murder rate in the country has turned South Africa into a place that "borders on a war zone". ${ }^{5}$ In short,s it will not be wrong to argue that South Africa is faced with a major disequilibrium, maybe even a disconnect, between the ideals of the human security paradigm and the practical, perhaps severe, realities of security confronting South Africans on a daily basis.

The threat agenda is a critical objective reality and the essence, one may argue, of the security debate. Frank Hoffman noted in a recent article in honour of Colin S Gray:

[S]trategy will retain its utility as long as security communities have interests, and as long as policymakers and military commanders need to counter challenges and align resources to obtain desired objectives. ${ }^{6}$ 
Thus, and by implication, as long as security communities exist, they will have to deal with the harsh realities of the threat agenda as a key driver of all security and strategic processes. Of course, the threat agenda is not the only variable and driver for security communities in their strategic processes. Yet, it is safe to argue that no strategic process will be legitimate without due consideration of the critical objective security realities of the threat agenda. ${ }^{7}$

The intelligence community has a decisive role in the exploration of the threat agenda. In general, the intelligence and scholarly communities make use of the same methodological practices to process information. The intelligence community processes information into actionable intelligence; the scholarly community processes information into purposeful knowledge. In the case of the intelligence community, the gathering and processing of information and the final intelligence products, comprises a closed, often confidential process, which is covered in secrecy. This brings a complex dynamic to the fore in terms of the reliability and validity of intelligence products and the range of variables and factors that have to ensure precisely that. ${ }^{8}$ In the academic community, the approach is always to be as transparent and as open as possible, and to submit the data, the methodological processes, and the final product of research to open and public debate and the scrutiny of peer reviews. The scholarly community in South Africa has an important responsibility in asking critical questions about the threat agenda as a key driver of the security debate.

Since the creation of the Union in 1910, South Africa has had to find a balance between the critical threat realities emanating from three key security domains irrespective of the ruling entity: security threats from outside Africa, from within Africa, and from within the borders of South Africa. ${ }^{9}$ From these three, the domestic threat agenda has always been the most prominent, and the current security situation is no exception in this regard. Thus, although all three threat domains have been analysed, it was done with an understanding that the current security situation is almost exclusively and predominantly shaped by domestic realties.

The article aims to present a scholarly demarcation of some of the most critical, important and key features of the South African security agenda using these three threat domains as a framework for discussion. The aim is not to downplay or discredit the intelligence processes or the human security agenda. Rather, an analysis of the South African threat agenda, by implication, is to raise serious concerns about the ability of the human security paradigm to deal with the current threat realities facing the country. The article also does not aim to reflect a detailed analysis of every item on the security agenda. Instead, the intention is to provide a framework for scholarly analysis and debate of the key features driving the South African security agenda. Methodologically, the article is inductive in nature, relying almost exclusively on a literature review and qualitative analysis of the issues under discussion. Arguing from a strategic studies perspective, the author relies almost exclusively on a neo-realist paradigm. 


\section{A word on security predicaments and threat perspectives}

The idea of human security has its roots in the theoretical perspectives on security popularised by Barry Buzan and others in the 1980s and early 1990s. Buzan delineates security as the pursuit of freedom from threat and the ability of states and societies to maintain their independent identity and their functional integrity against forces of change, which they see as hostile. ${ }^{10}$ For Buzan, security does not only concern the survival of the entity to be secured, but it also reasonably includes a substantial range of concerns about the conditions of existence. The 1990s consequently saw an existential debate on security in the post-Cold War literature on the so-called deepening and broadening of the security agenda. The 'deepening debate' centres on questions about which entity or entities, other than the state, should be secured, whilst the 'broadening debate' concerns the conditions of that security. The security debate in the 1990 s culminated in a general agreement that the state is not the only referent object of security, and that the security forces are not the only pathway to security; in fact, security - it is argued - is also about a range of political, economic, social, and other conditions that define the nature of security for the referent object. ${ }^{11}$

However, the debate on the all-embracing definition of security was very much a normative inside-out reflection on security as an ideal condition; an effort to conceptualise the ideal theoretical nature of security as a risk-free condition. Although the debate recognised that security is threatened from the outside, it did not concern itself much with the outside-in practical realities of the threat agenda in the post-Cold War world. The deliberations tended to centre mainly on domestic vulnerabilities as primary driver of security. In fact, as the debate on security unfolded in the 1990s, the threat agenda was very much open for debate and in flux. As the realities of the postCold War era unfolded in the 2000s, it became quite clear that the end of the Cold War was not, in the words of Francis Fukuyama, the end of history or the era of perfect peace that the world has been waiting for throughout its existence. ${ }^{12}$ More specifically, a view evolved that perhaps too much emphasis was placed on the de-militarised conceptions of security without due consideration of the harsh realities of the threat agenda and their influence on security. There was a growing recognition that, although other referent objects of security assisted in the creation of an understanding of what had to be secured, the role of the state and its security apparatus remained fundamental in and central to the process of security. ${ }^{13}$

Security, like strategy, is a highly philosophical notion with no independent physical reality; it is by nature highly elusive and conceptual. ${ }^{14}$ However, like strategy, security is at the same time, very much a practical notion rooted in questions about how it is to be achieved, whether the idea will work, and how it must be done. ${ }^{15}$ The question for South Africa is how to debate security in such a way as to contextualise the elusive theoretical setting; yet, at the same time, address the concrete practical realities of security facing South African citizens on a daily basis. In short, it is about how to breach the divide between the conceptual and the practical realities of security in South Africa. 
From a theoretical perspective, security has both an objective and subjective reality. It is objective to the extent that the threats facing South Africa are fundamental in affecting every citizen directly. The security and threat agenda, as such, is open for public discussion, debate, and speculation. The threats facing South Africans daily are a harsh objective reality. However, security is also subjective to the extent that it is government - i.e., political power - that provides security with content, demarcates the threat agenda, prioritises the items on the threat agenda, and foots the security bill. How do we align the practical objective realities of security facing South African citizens on a daily basis with the subjective, often ideological, views of government on security?

The South African threat agenda is expansive, open for debate and often constructed from the eye of the beholder. Expansive approaches to security, human security in the case of South Africa, are unavoidable if security is understood as being about alleviating the threats faced by the people rather than the state. However, expansive security agendas are notoriously difficult to deal with. Firstly, as Booth and others point out, placing threats in order of priority is a problem that must be resolved in the political process. Political processes are messy and loaded with animosity. ${ }^{16}$ The debate about the threat agenda then often translates into a threat-induced process. ${ }^{17}$ This is a very true and visible reality of security in South Africa with factors such as race and economic inequality often being important drivers in the debate about security.

Secondly, expansive security approaches tend to steer away from the military core of security and run the risk of being too broad to be of any practical value. In short, it is difficult to operationalise expansive approaches to security. Debates on human security often translate into deliberations about the general well-being of society. ${ }^{18}$ Quite where societal concerns cease to merit the urgency of the 'security' label - which identifies threats as significant enough to warrant emergency action and exceptional measures including the use of force - and become part of everyday uncertainties of life, is one of the difficulties of human security. ${ }^{19}$ Thus, expansive definitions of security that tend to place the emphasis on the well-being of society may translate into security as a concept losing much of its value as a theoretical and planning construct for the security community. Has this perhaps been the case in South Africa?

\section{International realities of South African insecurity}

It is difficult to make security predictions in a time that has seen the spreading of the COVID-19 virus as a major global 'black swan event'. It is possible, however, to demarcate a number of international developments that inform South African security realities at present. Firstly, and from a global balance-of-power perspective, the Trump doctrine of 'America first' seems to have created some interesting international leadership vacuums and opportunities as the United States (US) is stepping down from its role as international policeman and, more importantly, the funder of international organisations. ${ }^{20}$ The world order, constructed in the aftermath of the Second World War to serve mostly Western interests, and the post-Cold War era of US hyper-power status, is ending. The political and economic aspirations of both Russia and China and perhaps India as well - are on the rise, and both Russia and China approach the 
West with suspicion and distrust. ${ }^{21}$ From a strategic perspective, however, they face in opposite directions with Russia looking west and China looking east.

From a futures perspective, it is quite clear that Western countries are increasingly stepping away from involvement in African security or maintain a light footprint in terms of military boots on the ground. ${ }^{22}$ The strategy of the West towards African security is Clausewitzian in nature. Europe prefers old-school government-togovernment diplomacy. The United States relies on trade, the economy, low-level security assistance and, if they have to, the employment of unmanned kinetic systems for security purposes. ${ }^{23}$ The rising powers, specifically Russia, China and Turkey, tend to favour an indirect Sun Tzu approach. Their preference seems to lean towards longterm engagements with diplomacy that is much more personal, party-to-party and issuedriven. ${ }^{24}$ Their security involvement in Africa is often informed by arms transfers, ${ }^{25}$ cyber-driven approaches, and - if direct deployment is required - the employment of private military contractors as an extension of their intelligence apparatus. There is no doubt that they have extensive exploitive economic interests in Africa from both a raw materials and market perspective. Africa is however increasingly viewing their involvement in the continent in neo-colonial terms. It also set these powers up in direct competition to South African economic and security interests in Africa. ${ }^{26}$

Secondly, changing big-power geostrategic realities closely intertwines with regional security rivalry, dynamics and insecurities, and the evolvement, role and influence of failing and rogue states. For quite some time, the attention of the world, in this regard, has been on the Middle East region, and on countries like North Korea and Iran. The American idea of a Global War on Terror (GWOT) not only destabilises the balance of power relationships in the Middle East; it also creates new interregional animosities, complex emergencies and alliances. Moreover, it draws external forces of instability into the region. The ignition of smouldering regional instabilities, through external interference, is also spreading to and unfolding in Africa. This is clearly visible in places like Libya, Mali and the Sahel region. East Africa, with Somalia as epicentre, is also a growing concern. In Africa, outside interference is not always of a military nature. In the case of Mozambique and the arch of instability in the central regions of Africa, much of what had unfolded was - and still is - the result of economic opportunities. ${ }^{27}$

Thirdly, worldwide, political security is in decline; politics in general seems to be in a credibility and legitimacy crisis. ${ }^{28}$ More specifically, the 1990s idea of democracy as the general and quick-fix solution for many of the political problems in the world has faded with the Western liberal political agenda progressively turning on itself in a paradoxical self-destructive manner. ${ }^{29}$ Worldwide, the middle class is politically and economically in decline; the rich are getting richer and the poor are getting poorer. In a computerised globalised financial system, capital moves fast and easily to safe and stable locations. ${ }^{30}$ A number of key trends unfold in tandem with the growing political tension of a disappearing middle class and a liberal agenda that are to affect South African security directly. 
Since the end of the Cold War, ideology has lost much of its attractiveness or flavour as a tool for political enlistment. Instead, political mobilisation increasingly relies on anti-establishment rhetoric and religious preferences. Moreover, individualised political leadership and in-group/out-group political rhetoric drives the rise of political populism. Populism covers the broad political spectrum and includes a range of political stances that emphasise the idea of 'the people' and often juxtapose this group against 'the elite' ${ }^{31}$ The decline in liberal political tolerance, anti-establishment rhetoric and rising populism translates into a culture of violent protest at grassroots level. What unfolded in France and the United States were textbook examples in this regard. ${ }^{32}$ Violent protest is issue-driven and not necessarily based on party politics. Mobilisation is bottom-up, often highly emotional, and ranges across the broad political spectrum. Identity politics, lack of service delivery, religion and culture are key drivers of violent protests. ${ }^{33}$

Fourthly, demographics have always been and are again coming to the fore as a key feature of international politics and security. Both positive and negative migration reflects the reality of the current world order and of the African security landscape. Uncontrolled migration unfortunately often leads to tension and mutual feelings of enmity between the developed and developing worlds. The developing world is under pressure in the provision of basic needs and services, and the developed world is facing the reality of a growing pensioning population, skills shortages, and the policing of hardened borders. The impact of these political security realities is already unfolding in Southern Africa and is due to influence the South African security outlook in the years to come. ${ }^{34}$

Lastly, cyberspace is becoming both a positive and negative reality of international relations and security. Cyberspace relations are increasingly tying the world together, and the possibilities of cooperation and interaction between countries and a multitude of actors at different levels and in different spheres in the international domain are almost innumerable. The cyber domain is increasingly not only a complementary domain, but also an independent low-cost platform of near instantaneous interaction between states, and between state and sub-, trans-, and non-state actors. The stealth nature of cyber power, the possibility of non-attribution, and the dangers of cyber security raise the possibility of the offensive use of the cyber domain as an instrument of strategic effect. ${ }^{35}$ South Africa, in particular, is very vulnerable in this regard. ${ }^{36}$ The South African economy, its banking sector in particular, relies quite heavily on the cyber domain in its interaction with the rest of the world - and South Africa has not yet invested comprehensively in the cyber security domain. ${ }^{37}$ Both domestic and foreign criminals continue to target South African businesses, with increasing cases in the healthcare and financial services industries as a cause for concern. ${ }^{38}$ Thus, as the grandiose plans of the South African government for a "knowledge-based economy" unfolds, cyber security, especially protection against the offensive use of cyber from outside the African security domain, is to become a critical security concern. ${ }^{39}$ 


\section{African and regional insecurities}

What are the key features of the African strategic landscape that influence and shape South African security? This question is rooted in the reality that South Africa cannot exist as an island of stability - or instability - in a sea called Africa. African insecurity - conflict, violence and war in particular - always had a defining influence on the South African security outlook. As a point of reference, it will serve South Africa well to reflect on who the actors and the victims are in the contemporary African security landscape. States are not necessarily the only actors in the African security domain anymore. International, continental, and regional organisations and sub-, trans-, and non-state actors are growing as key role players in the African security domain. Indirect deaths, or what the West euphemistically refers to as 'collateral damage', is responsible for most of the deaths resulting from African insecurity: members from nongovernmental organisations (NGOs), humanitarian aid workers, refugees, women and children. These deaths are often exacerbated by disease and malnutrition in complex security emergencies. ${ }^{40}$ It is also worth noting that the political geography of African insecurity still matters with threats that are experienced more intensely in some areas than in other. These include war zones, informal settlements, townships and shanty towns, refugee and displacement camps and rural areas.

Insecurity in Africa, firstly, is mostly associated with armed conflict, and conflict has been a recurrent reality of African insecurity. African conflicts are diverse in nature - from post-colonial struggles to boundary and territorial disputes, secessionist movements and annexations, access to resources, identity conflicts, and conflicts induced by poverty, denial, and perceived or real injustices. ${ }^{41}$ The predictors of conflict in Africa, however, persist, and conflict is due to re-emerge. African states remain relatively poor; governments are weak; race, ethnicity, religion and geography divide societies; and populations are growing with large numbers of energetic, yet unskilled, unemployed and frustrated youths in urban concentrations. Moreover, most African democratic structures remain relatively weak, skills are low, finances scarce, incentives in favour of the private sector are rare, and identity and patronage remain an operating principle. In addition, there is no intellectual alternative to democracy in Africa. The process of democratic consolidation, however, is difficult, and democracy in Africa is not necessarily translating into good governance, services, and goods. ${ }^{42}$

In Africa, the use of armed forces at state level is driven principally by the struggle for access to state power and resources. Conflict occurring on the margins or outside of the society of states occurs for reasons other than acquiring state power and by a range of non-state actors. These include warlord factions, clans, tribes and various types of militias. Conflict in Africa will continue to unfold as protracted interstate violence, as contested government transitions are rooted in problems of democratic deficits and often minority rule, and violence manifests as mutual destabilisation between states. 
State-based armed conflicts are on the rise in Africa. This is also true of popular protests. Religion is a growing driver of conflict in Africa. And as is the case elsewhere in the world, African conflict will see a rise in the use of remote forms of violence, especially improvised explosive devices (IEDs) and suicide bombings. Environmental changes, together with a lack of growth in service delivery capabilities, nurture the growth of livelihood struggles in Africa. ${ }^{43}$ Armed conflict often translates into regional insecurities and complex emergencies.

Secondly, religion is a growing source of conflict, instability, and insecurity in Africa. For South Africans, the idea of radical Islam comes heavily loaded with ideological and political baggage and provokes strong emotions either way. ${ }^{44}$ Paul Collier argues that the rise of radical Islam, together with an exponential growth in natural resource extraction, is the most critical threat facing Africa. ${ }^{45}$ A recent report by the African Center for Strategic Studies, notes that African militant Islamist groups have of late seen a nearly uninterrupted growth in violent activity. However, the focus of these groups shifted over time. Militant groups in the Sahel, the Lake Chad Basin and Mozambique have exhibited the sharpest increases in violent activity over the past year. This goes hand in hand with an expansion in violence against civilians ${ }^{46}$ (see Figure 1).

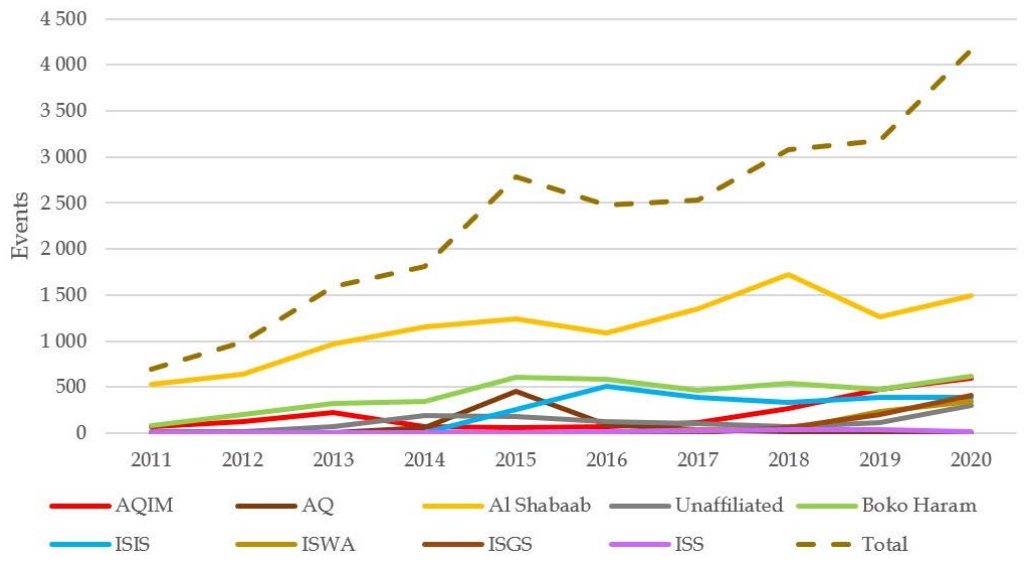

Figure 1: Violent events involving militant Islamist groups in Africa. ${ }^{47}$

Islamic induced conflicts in sub-Saharan Africa are at the receiving end of an influx of so-called 'foreign fighters', with the influx in Mozambique having the potential to affect South African security directly. ${ }^{48}$ Foreign fighters may join a militant group from a foreign state, regional or otherwise. In Africa, foreign fighters normally arrive in small groups from a neighbouring state. Three particular factors seem to underpin the current influx of foreign fighters: the growing propagation of Islamic insurgency; the escalation of inter-militant competition in various complex emergencies; and the detrimental effect of the COVID-19 crisis on state capacity, border security and economic growth. These trends are clearly visible in Mozambique, for example. The arrival of foreign fighters 
tends to make Islamic insurgencies more resilient to military defeat, as these fighters have an expanding effect on the tactical toolbox of the insurgent movement. Moreover, foreign Islamic insurgents often increase the severity of targeted violence against civilians in a conflict area. ${ }^{49}$ Mozambique is a textbook example of what happens if these trends coincide in time and place. The convergence of radical Islam, natural resource exploitation, and influx of foreign fighters in the future will cause African insecurity to increase in complexity and intensity. ${ }^{50}$ For South Africa, in particular, this will have direct security implications.

Thirdly, resource exploitation, the so-called 'resource curse', is not a new phenomenon in Africa. The exploitation of African resources by out-of-area actors has a history that predates the colonial period in Africa. Yet, Africans mostly associate the colonial and the post-independent Cold War periods with the exploitation of African resources. ${ }^{51}$ From a security perspective, Africa's economy is dependent on both resources and the export of raw materials. Yet, it is also vulnerable because of its resources. Africa's real economic challenge is its inability or failure to industrialise and process its resources and raw materials into consumer goods and products inside Africa. Without a value-added industrialised economy, the resource curse will persist. And Africa will remain dependent on exports and without the jobs that are urgently needed for the growing population. ${ }^{52}$

At present, though, Africa is moving into a third cycle of dependency and exploitation in the aftermath of, firstly, the colonial era and, secondly, the Cold War period of conflict and exploitation. Whereas European countries plundered African resources in the colonial period, and Russia, the United States and countries like Cuba were the key role players in Africa during the Cold War, it seems as if China, and more recently also Russia and Turkey, have become the primary beneficiaries of African resources in the post-Cold War era. The models of exploitation differ from period to period. More recently, China seems to be willing to invest comprehensively in the building of infrastructure and capital projects in Africa. Whereas the Western model was based on keeping Africa dependent by means of 'aid', China is providing their assistance by means of favourable loans that have to be paid back over time, often through favourable access to African resources. Many of the capital projects in Africa, however, are executed with foreign capital, foreign labour and foreign equipment. The projects do not necessarily translate into knowledge and skills transfer, African job creation, and the development of the African labour market. South Africa, in particular, has seen a tremendous process of de-industrialisation in the last 20 years. Not only does South African companies have to compete with these powers in Africa but, as a state involved in a process of de-industrialisation, South Africa will also become more dependent on the export of raw materials and resources to many of these powers. ${ }^{53}$

Fourthly, organised crime is a growing driver of insecurity in Africa that will affect South African insecurity directly. ${ }^{54}$ Organised crime is closely linked to corruption from a stability and security perspective. In Africa, organised crime networks - as is the case in Mozambique at present - have been involved in the illicit trade in wildlife, timber, gems, gold and narcotics, including heroin, as well as human trafficking. ${ }^{55}$ The 
corruption that the organised crime networks promote often involve state actors, such as the police. Corruption in African security forces frequently exacerbates the public's distrust of government and feeds the narrative that the government is not on the side of populace. ${ }^{56}$

Transnational organised crime obviously has a regional and often also international interface. Tanzanians and people from Mali, Ethiopia, the Democratic Republic of the Congo, Rwanda, Somalia, Nigeria and Cameroon, for example, are involved in the criminal markets of northern Mozambique. The same is true of criminal groups from South Asia (heroin), China (timber and ivory) and Thailand (gems) in various countries in Southern Africa. Drugs produced in Afghanistan are transported along the maritime trade routes along the East African coastline from Somalia to northern Mozambique. Heroin enters Mozambique via the port of Pemba in Cabo Delgado and that of Nacala in neighbouring Nampula Province. Large shipments of heroin are also entering Mozambique by road from Tanzania and Kenya. Bribery and a general lack of law enforcement accompany these criminal activities. The heroin arriving by road and in the ports is then shipped by road to South Africa and much of it by air to Europe. ${ }^{57}$

Organised crime and resource exploitation often converge in the growing insecurity resulting from the exploitation of African wildlife, flora and fauna. African wildlife, flora and fauna are also in competition with the livelihood struggles of African people due to worldwide climate and environmental changes. ${ }^{58}$ The most critical socalled 'green security issue' in Africa is the surging demand for ivory and rhino horn, especially in Asia, which has put Africa's elephants and rhinoceroses on the path to extinction. ${ }^{59}$ Yet, as the Organised Crime Index Africa 2019 points out, organised crime is often overlooked because the harms caused by organised crime are usually obscured in the 'underworld', hidden in the shadows of remote borderlands, concealed in secret jurisdictions, or felt most keenly by underserved communities in Africa. ${ }^{60}$

Fifth, the realities of African insecurity are affecting African demographics, as people are trying to escape conflict, hunger, poverty and deprivation. ${ }^{61}$ The 2018 State of peace and security in Africa (SPSA) report notes that intra-African migration towards cities and more prosperous countries and regions will continue to accelerate and grow into a bigger challenge in the years to come as the migration overlaps with other structural weaknesses that African governments are not in a position to tackle with determination. ${ }^{62}$ More specifically, African governments seem to have little political will and capacity to deal with the problem of illegal migration in a comprehensive manner. Simply throwing money at the issue is unlikely to address the underlying structural issues that create youth and citizen vulnerabilities underpinning the problem of illegal migration. ${ }^{63}$

In South Africa, the large influx of illegal and undocumented migrants already led to an outburst of xenophobic attacks, especially in poor and informal communities where these immigrants compete with South Africans for jobs and access to goods and services. France Maphosa and Christopher Ntau outline the nature of this problem in Africa by arguing that, while migrants in general, whether documented or undocumented, are 
targets of violence, exploitation and discrimination in many countries, undocumented migrants are particularly vulnerable because of their 'illegal' status. Although violence against undocumented migrants is not formally endorsed by African states, their description as a problem or a threat to society places such migrants in a state of exception, which is virtually outside the protection of the law. ${ }^{64}$ This is not a problem that will fade from either the African or South African security landscape in the years to come; instead, it is growing in intensity and scope. ${ }^{65}$ In South Africa, for example, this has most recently played out in deadly attacks on 'foreign' truck drivers.

Lastly, from a statutory defence perspective, the point needs to be made that Africa is perhaps the most under-defended piece of real estate in the world ${ }^{66}$ Foreign military interventions in Africa exacerbate this problem as it often translates into a lack of urgency and professionalism in African armed forces - a mentality of 'someone else will take care of our problems' ${ }^{67}$ Otto von Bismarck is often quoted for having said that there will always be a military within the borders of the state: either one's own or that of someone else. In Africa, that 'other' military is often a rebel movement, an intervening non-African foreign military, a peacekeeping force, or the military of a neighbouring state. This is not to say that professional armed forces are not to be found in Africa ${ }^{68} \mathrm{In}$ Africa in general, however, nothing is indicative of the fact that the disregard for their armed forces is due to change in the near future, as African states continue down the path of military neglect, military corruption and under-budgeting for defence. ${ }^{69}$

The lack of credible defence capabilities in many African countries is a key driver in the efforts by the African Union to develop a comprehensive peace and security architecture for Africa. The so-called African Peace and Security Architecture (APSA) focuses specifically on conflict prevention, conflict management and peace building. ${ }^{70}$ APSA is operationalised by initiatives that include a Continental Early Warning System (CEWS) and an effort to set up an African Standby Force (ASF) by means of a so-called Regional Mechanism (RM). One of the enduring challenges facing APSA, however, is capacity. Financially, it is strongly dependent on external sources, and for troop and capacity contribution, on the member states. ${ }^{71}$

South Africa is a key state in the security structure of the Southern African Development Community (SADC). Although South Africa's declared approach to security challenges in Africa has always emphasised the need for cooperation and multilateral approaches, the reality of South African involvement in APSA is one of pragmatism. South African military deployments in Lesotho, Burundi, the Central African Republic and the Democratic Republic of the Congo clearly reflected this reality. ${ }^{72}$ How this is to unfold in future in South Africa's involvement in APSA and how it is to influence South African security itself, are open for debate.

\section{South African domestic insecurities}

South African domestic security always had a dynamic of its own. The dialectic between external threats and internal vulnerabilities drives this dynamic. A number of key variables decisively influence South African dynamics at present. 
Firstly, South African border security is located on the fault line between external threats and internal vulnerabilities and will grow in importance in future. The effective management of South African borders underpins three critical domains of South African insecurity: negative and illegal migration from the rest of Africa, the interaction of violent and organised crime from within with what is unfolding in the region, and transnational green and environmental security. ${ }^{73}$ The latter is a direct result of the poaching of South African wildlife on land and at sea. The critical challenge that has not yet been resolved by South African security forces is that these challenges are neither domestic nor foreign; they unfold in the fault lines between these domains. As a forthcoming attraction, the doubt within the South African security services about who is responsible for what in addressing these security challenges, needs to be resolved. Moreover, the question of whether South African borders should be managed as hard or soft borders has to be settled as a matter of urgency in the name of improved security. ${ }^{74}$

Secondly, it is almost impossible to consider and assess the drivers, and the dialectic among the drivers, of the growing criminal insurgency ${ }^{75}$ facing South African society. However, the insurgence is deeply rooted in the lack of economic growth, government corruption and - because of the interplay between these two - an exponential decline of governance and services. This is amplified by a growing lack of proficiency in the government sector, especially in rural areas. These realities ought to be tied to the argument by Killebrew that crime, terrorism, and insurgency differ mainly in scale, and distinctions are becoming less meaningful in the contemporary era. ${ }^{76}$ One must accept that the scale of the problem is a threat to the security and stability of the state. No doubt, though, that organised crime, corruption, lawlessness, and extreme levels of homicide in certain geographical areas and communities in South Africa are increasingly threatening the stability of the country as a whole. ${ }^{77}$ Mentally and geographically, South Africa increasingly functions in enclaved mode at provincial, municipal and neighbourhood level. Instead of becoming a more integrated and open society, it tends to be more siloed, exclusive and cocoonistic. ${ }^{78}$ There is absolutely no indication that government will be able to alter these trends and realities significantly in future. ${ }^{79}$

Thirdly, recent developments involving the professionalism of the security forces in the SADC region do not bode well for the future. The security forces are often closely aligned with the ruling party and enmeshed in its factional politics. ${ }^{80}$ Their constitutions may insist that the security services must be politically non-partisan. However, the executives and the ruling parties constantly blur the boundaries between the party and the state bureaucracy. ${ }^{81}$ This situation is reinforced by the enduring affinity between politicians of the ruling party and members of the security forces who served together during the liberation struggles. ${ }^{82}$ Not only are officers who are seen as loyal often not retired from service; their service increasingly appears to be based on personal loyalties and connections rather than on professional integrity and loyalty. ${ }^{83}$ Thus, instead of the security community and political domains serving the interests of society, society and the security forces are increasingly expected to serve the interests of the ruling elite. ${ }^{84}$

In South Africa and from a civil-military perspective the oversight over the security forces is a growing cause of concern. This is tied to the growing disregard in both the 
executive and the security forces for the position and role of Parliament. Not only are senior members of the security forces reluctant to appear in front of oversight committees of Parliament; ${ }^{85}$ they also treat these committees with an attitude of "we are not their clients and [we] only take instruction from the Commander-in-Chief (President Cyril Ramaphosa)". ${ }^{86}$ Oversight is also hindered by a growing tendency to cloud all issues of a security nature in excessive secrecy. Obviously, certain matters need to be kept secret. ${ }^{87}$ Nevertheless, confidentiality should be informed by the democratic principle of what is in the public interest. As Laurie Nathan points out, higher levels of secrecy tend to lead to less public scrutiny and a greater risk of abuse of power. ${ }^{88}$

From a practical and operational perspective, the security forces in South Africa seem to be increasingly reluctant to act and to enforce law and order. This is perhaps a legacy of the Marikana incident. ${ }^{89}$ Operational doubt seems to be rooted in several key trends that will be decisive in how security forces in South Africa fulfil their roles in future. A lack of political will or, to put it differently, the difficulty of grassroots-level interpretation of the mixed bag of intentions and double-talk at political and policy level creates tactical confusion and an understanding that there is no institutional or political accountability for operational misfortunes; the individual will be thrown under the bus. ${ }^{90}$ Professional trust, up and down the line of command, seems to be lacking. In addition, a lack of sufficient and professional training and experience feeds professional doubt in the security forces. A question in the mind of the individual member of the security forces about precisely how to deal with a particular situation, immediately translates into reluctance to act. Professional behaviour cannot be of a high standard if the training an individual receives is not of a high standard. ${ }^{91}$ Moreover, social media scrutiny implies that security forces are under observation at all times and, thus, they are reluctant to act. Unfiltered recording and distribution of security force behaviour are difficult to deal with and, unlike the security forces of more advanced states, the South African security forces have not exploited the benefits of in-time recordings.

Lastly, and this is not necessarily part of the threat agenda per se, much of the stability inside the country centres on the ability of the ruling ANC alliance to resolve the tensions within the ruling entity in a peaceful and constructive manner. In the process, the ANC needs to deal with a number of ideological, structural and political tensions that threaten to pull the organisation apart. A tension with which the ANC has had to deal since 1994 is the contradiction between the ANC as liberation movement and the ANC as governing entity. As an umbrella movement for liberation, the ANC accommodated ideological diversity. For the ANC as a governing entity, ideological diversity translates into policy vagueness and an absence of clear policy decisions. ANC governance is therefore characterised by incoherence, confusion and even gridlock as policy vacillates to appease various factions. ${ }^{92}$

Another tension is the unstable balance between labour - COSATU ${ }^{93}$ by implication - and the SACP, ${ }^{94}$ on the one hand, and the South African business sector on the other. For the ANC as a ruling entity, this translates into a dichotomy of what is economically essential for South Africa, is often politically unacceptable for the ANC as political movement; and what is politically feasible for the movement is often economically 
destructive for the country. ${ }^{95}$ This tension is due to growth in intensity as a virtually bankrupt National Treasurer needs to manage the public sector wage bill and possible job losses. A last tension is the underlying factionalism in the ANC with its roots in economic self-interests, corruption and state capture. The project to repair the integrity of the state has to reveal the depth of the underlying conflict between these different factions within the ANC. The calibrated management of this process of state healing may have a defining effect on the security of the country as a whole.

\section{Conclusions and recommendations}

Looking towards the future from a continental and regional security perspective, outside-of-Africa involvement in African insecurities will affect the South African security and leadership positions directly. Two critical questions drive the South African security debate from this perspective. The first is whether and how South Africa should be involved in regional security instabilities - diplomatically, militarily or economically? The second is what the effect on South African security will be, whether or not the country becomes involved in these regional complex emergencies, probably alongside non-African powers. Mozambique will be the first serious case study. Direct involvement may have a serious knock-on effect. Not doing anything will however have exactly the same outcome.

The negative synergy between a negative democratic agenda, the credibility and legitimacy crisis of politics in South Africa, and a growing culture of political populism and violent protest will sustain political insecurity in South Africa in years to come. The economy will be affected in both an input and output reality. The lack of economic growth and recovery in the wake of the COVID-19 crisis is to become a key driver in the growing process of instability. Political insecurity, violence and uncertainty, at the same time, inhibit South African economic growth, recovery and service delivery. A difficult challenge to manage! From a security perspective, border management and protection should be a matter of priority. Not only should the South African decisionmakers articulate a clear vision in terms of the hard or soft management of South African borders; in the management of South Africa's borders, there should be clarity in terms of precisely who is responsible for what from a security perspective.

It is quite clear that it is perhaps also time to reflect critically on the human security paradigm as a pathway to address the key features of the South African security predicament. At present, very few of the key drivers of the South African security agenda have their roots in the human security domain. In fact, South Africa seems to have come full circle from national security before 1994, to human security under Mandela, to state security under Zuma. However, the problem with a more traditional and state-driven approach to security and - specifically from a security sector perspective - is that the security services increasingly serve out of loyalty and at the behest of the president and the ruling party, not necessarily the citizens or the Constitution. ${ }^{96}$ This poses a severe threat to democracy in South Africa and the ability of the country to deal with the key features of the security agenda. The professionalism of the security forces in South Africa should be a matter of priority. 
The private security industry is indeed a flourishing and, very often, effective alternative in the domestic security domain. Yet, it cannot address the full spectrum of security challenges facing the country. This brings the critical dichotomy of strategy to the fore. If political and security decision-makers are unwilling to make tough decisions on security, they - in fact - abdicate their ability to shape the outcome of South Africa's security predicaments. Strategic reality does not pause for decisions in anticipation of what may be; it necessitates and dictates decisions! Strategic paralysis in the security domain is therefore often catastrophic. 


\section{ENDNOTES}

${ }^{1}$ Abel Esterhuyse is an Associate Professor and Head of the Department of Strategic Studies at the Faculty of Military Science at Stellenbosch University.

2"South Africa's troubled outlook". Strategic Comments 25/7. 2019. iv-vi. doi: $10.1080 / 13567888.2019 .1668128$

${ }^{3}$ United Nations. "What is human security?" No date. Online Publication. $<\underline{\text { https: } / / w w w . u n . o r g /}$ humansecurity/what-is-human-security/ $>$ Accessed on 15 May 2021.

${ }^{4}$ United Nations. "Human development report 1994". 1995. < $\underline{\text { http://hdr.undp.org/sites/default/ }}$ files/reports/255/hdr 1994 en complete nostats.pdf $>$ Accessed on 15 May 2021.

${ }^{5}$ Staff Writer. "Here's how South Africa's crime rate compares to actual warzones". Businesstech. 18 September 2018. < https://businesstech.co.za/news/lifestyle/271997/hereshow-south-africas-crime-rate-compares-to-actual-warzones/ $>$ Accessed on 15 May 2021.

${ }^{6}$ F Hoffman. "Distilling the essence of strategy". War on the Rocks. 4 November $2020 .<\underline{\text { https: } / /}$ warontherocks.com/2020/08/distilling-the-essence-of-strategy/> Accessed on 15 May 2021.

${ }^{7}$ AJ Esterhuyse \& G Louw. "The practice of strategy: South African defence in stasis". Defence \& Security Analysis 34/1. 2018. 53-72. doi: $\underline{10.1080 / 14751798.2018 .1421403}$

${ }^{8}$ The South African intelligence agencies are facing an existential problem in this regard at present. See L Nathan. "Who's keeping an eye on South Africa's spies? Nobody, and that's the problem". The Conversation. 25 September 2017. $<$ https://theconversation.com/ whos-keeping-an-eye-on-south-africas-spies-nobody-and-thats-the-problem-84239> Accessed on 15 May 2021.

${ }^{9}$ See the discussion in the introduction in I van der Waag. The military history of modern South Africa. Johannesburg: Jonathan Ball, 2015.

${ }^{10}$ B Buzan. People, states \& fear: An agenda for international security studies in the post-cold war era. Sussex: ECPR Press, 2008, 11.

${ }^{11}$ B Buzan. "New patterns of global security in the twenty-first century". International Affairs 67/3. 1991. 432-433. <https://www.jstor.org/stable/pdf/2621945.pdf?refreqid=excelsior\%3Adf209ab9ccaf540c5be988b35ab69d5c $>$ Accessed on 15 May 2021.

${ }^{12}$ Fukuyama is known for his book The end of history and the last man, which was published in 1992. In the book, Fukuyama argues that following the rise of Western liberal democracy after the Cold War and the disintegration of the former Soviet Union (1991), the world has reached "not just ... the passing of a particular period of post-war history, but the end of history as such: That is, the end-point of mankind's ideological evolution and the universalization of Western liberal democracy as the final form of human government". Stated differently, he argues that the world has entered a period of permanent and sustainable peace. See F Fukuyama, "The end of history?" The National Interest 16. Summer 1989. 4.

${ }^{13}$ See the introduction to J Baylis, JJ Wirtz \& CS Gray (eds), Strategy in the contemporary world, $6^{\text {th }}$ ed. Oxford: Oxford University Press, 2019.

${ }^{14}$ CS Gray, "So what! The meaning of strategy". Infinity Journal 6/1. 2018. 4-7. < https://www. militarystrategymagazine.com/article/So-What-The-Meaning-of-Strategy/ $>$ Accessed on 15 May 2021.

${ }^{15}$ See the introduction to Baylis et al. op. cit.

${ }^{16}$ See K Booth. Theory of world security. Cambridge: Cambridge University Press, 2007.

${ }^{17}$ The 'debate' on the issue of prioritising farm murders in South Africa as a 'priority crime area' is a typical example in this regard. 
${ }^{18}$ J Baylis \& JJ Wirtz. "Introduction: Strategy in the contemporary world". In Baylis et al. op. cit., pp. 1-15.

${ }^{19}$ Buzan, "New patterns of global security ..." op. cit., pp. 432-433.

${ }^{20}$ J McArthur \& K Rasmussen. "Who actually funds the UN and other multilaterals?" Order from Chaos. Brookings. 9 January 2018. $<$ https://www.brookings.edu/blog/order-from-chaos/2018/01/09/who-actually-funds-the-un-and-other-multilaterals/ Accessed on 15 May 2021.

${ }^{21}$ PB Stares, Q Jia, N Tocci, D Jaishankar \& A Kortunov. "Perspectives on a changing world order". Discussion Paper Series on Managing Global Disorder No. 1. Council of Foreign Relations. June 2020. $<$ https://cdn.cfr.org/sites/default/files/report_pdf/discussion-paper-collection stares-et-al final-with-cover.pdf $>$ Accessed on 15 May 2021.

${ }^{22}$ D Monyae. "The US, Russia, China and Africa in the evolving global order". UJCI Africa-China Policy Brief No. 3. The University of Johannesburg Confucius Institute. 2017. $<$ http://confucius-institute.joburg/wp-content/uploads/2017/11/UJCI-africa-china-policy-brief-no-3.pdf $>$ Accessed on 15 May 2021.

${ }^{23}$ F Tomas, TF Husted, A Arieff, L Ploch Blanchard \& N Cook. "US assistance to sub-Saharan Africa: An overview". Congressional Research Service. 20 May 2020. $<$ https://www. everycrsreport.com/files/20200520_R46368_85b8c6dfb93ce5e04bd19ab939fc$11 \mathrm{~cd} 6 \mathrm{f} 8 \mathrm{db} 649 . \mathrm{pdf}>$ Accessed on $1 \overline{5}$ May 2021.

${ }^{24}$ P Nantulya. "China promotes its party-army model in Africa". Spotlight. Africa Center for Strategic Studies. 28 July 2020. <https://africacenter.org/spotlight/china-promotes-its-party-army-model-in-africa/> Accessed on 15 May 2021.

${ }^{25}$ I Mushekwe. "China places strategic ground to air missiles in Zimbabwe". Bulawayo 24 News. 29 August 2018. <https://bulawayo24.com/index-id-news-sc-national-byo-143959. html $>$ Accessed on 15 May 2021.

${ }^{26}$ C Chien-Kai. "China in Africa: A threat to African countries?" Strategic Review for Southern Africa 38/2. 2016. 100-122. <https://www.up.ac.za/media/shared/85/Strategic $\% 20$ Review/Vol\%2038(2)/chen-pp100-122.zp104540.pdf > Accessed on 15 May 2021; A Kinyondo. "Is China recolonizing Africa? Some views from Tanzania". World Affairs 182/2. 2019. 128-164. doi: $10.1177 / 0043820019839331$

${ }^{27}$ E Beevor \& F Berger. "ISIS militants pose growing threat across Africa". IISS. 2 June 2020. $<$ https://www.iiss.org/blogs/analysis/2020/06/csdp-isis-militants-africa $>$ Accessed on 15 May 2021.

${ }^{28}$ H Kriesi. "Democratic legitimacy: Is there a legitimacy crisis in contemporary politics?" Politische Vierteljahresschrift 54/4. 2013. 609-638. <https://www.jstor.org/stable/24201256?seq=1\#metadata info_tab_contents $>$ Accessed on 15 May 2021.

${ }^{29}$ This is not necessarily an ideological or scholarly view that is shared by all IR and IPE scholars. They may question the idea that liberal democracy or the liberal political agenda is 'self-destructive'. However, see Chapter 7 titled "Mass protests and riots as the 'new normal' in Africa" in O Ismail. State of peace and security in Africa (SPSA) report. Institute for Peace and Security Studies, Addis Ababa University, 2018, 41-47. $<$ https://media.africaportal.org/documents/Reforming_for_Peace_Security_Africa. pdf $>$ Accessed on 15 May 2021.

${ }^{30}$ B Francois. "Inequality and globalization: How the rich get richer as the poor catch up". Foreign Affairs 95. 2016. 11-15. < $<$ https://heinonline.org/HOL/Page?collection=jour-

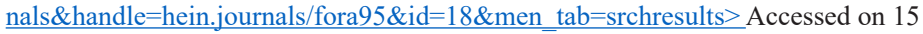
May 2021.

${ }^{31}$ Friedman, U, "What is a populist? And is Donald Trump one", The Atlantic 27, 2017. $<$ https:// www.theatlantic.com/international/archive/2017/02/what-is-populist-trump/516525/> Accessed on 15 May 2021. 
${ }^{32}$ See D Acemoglu. "Trump won't be the last American populist: The conditions that produced him need to be understood to be addressed". Foreign Affairs. 6 November 2020. $<$ https://www.foreignaffairs.com/articles/united-states/2020-11-06/trump-wont-belast-american-populist> Accessed on 15 May 2021.

${ }^{33}$ The Media Online. "Watch: 'We are at war', Daily Maverick’s Richard Poplak”. 30 September 2020. $<$ https://themediaonline.co.za/2020/09/watch-we-are-at-war-daily-mavericks-richard-poplak/?fbclid=IwAR3Nn6QdX47 V-tO6PJsEWJLM-UNBxigY4lbyLEjdmfxnNJkmdP2qUY4M5Q $>$ Accessed on 15 May 2021.

${ }^{34}$ For an in-depth discussion, see JA Goldstone, EP Kaufmann \& MD Toft (eds). Political demography: How population changes are reshaping international security and national politics. Oxford: Oxford University Press, 2012.

${ }^{35}$ See JB Sheldon. “The rise of cyberpower". In Bayliss et al. op. cit., pp. 291-307 for an indepth discussion in this regard.

${ }^{36}$ E Sutherland. "Governance of cybersecurity: The case of South Africa". The African Journal of Information and Communication 20. 2017. 83-112. $<$ http://www.scielo.org.za/scielo. php?script=sci arttext\&pid=S2077-72132017000100005 $>$ Accessed on 15 May 2021.

${ }^{37} \mathrm{C}$ Kahla. "SA, Kenya and Nigeria report highest cyber-attacks in Africa". The South African. 24 September 2020. $<$ https://www.thesouthafrican.com/technology/cyber-security-south-africa-kenya-nigeria/>Accessed on 15 May 2021.

${ }^{38}$ Blue Turtle Technologies. "Cyber crime a pandemic hitting the wallet of South African business". 6 August 2020. <https://www.itweb.co.za/content/JN1gPvOYBWPMjL6m> Accessed on 15 May 2021.

${ }^{39}$ The Presidency, Republic of South Africa. "South Africa scenarios 2025: The future we chose?" September 2018, Slide 70. $<$ https://www.gov.za/sites/default/files/gcis_document/201409/sascenarios20250.pdf $>$ Accessed on 15 May 2021.

${ }^{40}$ P Williams. "War". In P Williams (ed), Security studies: An introduction. Routledge, Oxon, 2008, 151-170.

${ }^{41}$ O Obasanjo. "On the state of peace and security in Africa". Prism 5/2. 2015. 10. $<\underline{\text { https://cco. }}$ ndu.edu/Portals/96/Documents/prism/prism 5-2/PRISM5-2 On the State of Peace. pdf $>$ Accessed on 15 May 2021.

42 J Herbst \& G Mills. "Emerging risks and opportunities in sub-Saharan Africa". Prism 5/2. 2015. 14-29. <https://cco.ndu.edu/Portals/96/Documents/prism/prism 5-2/ PRISM\%20V5N2\%20-\%20Africa\%203 19.pdf $>$ Accessed on 15 May 2021.

${ }^{43}$ See the discussion by Paul Williams for an in-depth outline in this regard: P Williams. "Continuity and change in war and conflict in Africa". Prism 6/4. 2017. 33-45.

${ }^{44}$ P Fabricius. "How serious is the Islamic State threat to attack South Africa?" ISS Today. 23 July 2020. $<$ https://issafrica.org/iss-today/how-serious-is-the-islamic-state-threat-to-attacksouth-africa $>$ Accessed on 15 May 2021.

${ }^{45}$ P Collier. "Security threats facing Africa and its capacity to respond". Prism 5/2. 2015. 31-41. https://cco.ndu.edu/Portals/96/Documents/prism/prism 5-2/PRISM5-2_Security Threats.pdf $>$ Accessed on 15 May 2021.

${ }^{46}$ Africa Center for Strategic Studies. "African militant Islamist groups set record for violent activity”. Spotlight. 21 July 2020. $<$ https://africacenter.org/spotlight/african-militant-islamist-groups-new-record-violent-activity/>Accessed on 15 May 2021.

${ }^{47}$ Ibid.

${ }^{48}$ E Morier-Genoud. "The jihadi insurgency in Mozambique: Origins, nature and beginning”. Journal of Eastern African Studies 14/3. 2020. 398. doi: $10.1080 / 17531055.2020 .1789271$

${ }^{49}$ AC Doctor. "The looming influx of foreign fighters in sub-Saharan Africa". War on the Rocks. 18 August 2020. $<$ https://warontherocks.com/2020/08/the-looming-influx-of-foreignfighters-in-sub-saharan-africa/>Accessed on 15 May 2021. 
${ }^{50} \mathrm{H}$ Decis. "Mozambique insurgency: A port at the centre of a storm". Military Balance Blog.

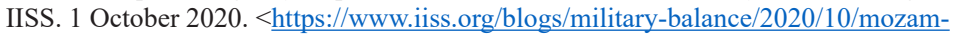
bique-insurgency> Accessed on 15 May 2021.

${ }^{51}$ AO Henri. "Natural resources curse: A reality in Africa". Resources Policy 63. October 2019. 1-13. <https://www.sciencedirect.com/science/article/pii/S0301420719300388> Accessed on 15 May 2021.

${ }^{52}$ See the excellent discussion in this regard in M Morris \& J Fessehaie. "The industrialisation challenge for Africa: Towards a commodities based industrialisation path". Journal of African Trade 1/1. 2014. 25-36. < https://www.sciencedirect.com/science/article/pii/ $\underline{\mathrm{S} 221485151400005 \mathrm{X}>\text { Accessed on } 15 \text { May } 2021 .}$

${ }^{53}$ P Nguimkeu \& A Zeufack. "Manufacturing in structural change in Africa". Policy Research Working Paper No. 8992. World Bank. August 2019. <https://papers.ssrn.com/sol3/ papers.cfm?abstract id=3440368 $>$ Accessed on 15 May 2021; also see CH Johnson. "Introduction: De-industrialization and globalization". International Review of Social History 47. Supplement 10: De-industrialization: Social, Cultural, and Political Aspects. 2002. 27. <https://www.cambridge.org/core/services/aop-cambridge-core/ content/view/B7DAC9E50FB38531DF58485F7F9A1D10/S0020859002000767a.pdf/ de-industrialization-and-globalization.pdf $>$ Accessed on 15 May 2021.

${ }^{54}$ See Global Initiative against Organized Crime. “Organised Crime Index Africa 2019”. 24 September 2019. < https://globalinitiative.net/wp-content/uploads/2019/09/enact report. pdf $>$ Accessed on 15 May 2021; also see the webpage "Combating organized crime" of the African Center for Strategic Studies for a more comprehensive understanding of the problem in Africa. $<$ https://africacenter.org/security-topic/combating-organized-crime $>$ Accessed on 15 May 2021.

${ }^{55} \mathrm{~V}$ Felbab-Brown. "Wildlife and drug trafficking, terrorism, and human security realities, myths, and complexities beyond Africa". Prism 7/4. 2018. 124-136. $<\underline{\text { https://cco. }}$ ndu.edu/Portals/96/Documents/prism/prism7 4/181204_FelbabBrown_PDF.pdf?ver=2018-12-04-161238-260>Accessed on 15 May 2021.

${ }^{56}$ S Ellis \& M Shaw. "Does organized crime exist in Africa?" African Affairs 114/457. 2015. 505-528. < https://academic.oup.com/afraf/article/114/457/505/2195165>Accessed on 15 May 2021.

${ }^{57}$ G Pirio, R Pittelli \& Y Adam. "The many drivers enabling violent extremism in northern Mozambique". Spotlight. African Center for Strategic Studies. 20 May 2020. $<\underline{\text { https:// }}$ africacenter.org/spotlight/the-many-drivers-enabling-violent-extremism-in-northern-mozambique/>Accessed on 15 May 2021.

${ }^{58}$ Williams, "Continuity and change ..." op. cit., pp. 33-45.

${ }^{59}$ B Anderson \& J Jooste. "Wildlife poaching: Africa's surging trafficking threat". Africa Security Brief No. 28. Africa Center for Strategic Studies. 31 May 2014. $<\underline{\text { https: } / / \text { africacenter. }}$ org/publication/wildlife-poaching-africas-surging-trafficking-threat/ $>$ Accessed on 15 May 2021.

${ }^{60}$ Global Initiative against Organized Crime op. cit., p. 8.

${ }^{61}$ For a comprehensive analysis of the problem of migration in Africa, see the recently published book by V Gumede, SO Oloruntoba \& SD Kamga. Regional integration and migration in Africa: Lessons from Southern and West Africa. Leiden: Brill, 2020.

${ }^{62}$ Ismail op. cit., pp. 26-31.

${ }^{63}$ Department of Economic and Social Affairs, United Nations. "International Migration Report 2015". 2016. < $\underline{\text { https://www.un.org/africarenewal/sites/www.un.org.africarenewal/files/ }}$ MigrationReport2015 Highlights.pdf $>$ Accessed on 15 May 2021.

${ }^{64} \mathrm{~F}$ Maphosa \& C Ntau. "Undocumented migrants as Homo Sacer: Cases from Botswana and South Africa". Journal of Asian and African Studies. 13 August 2020. 1. doi: $\underline{10.1177 / 0021909620946349}$ 
${ }^{65}$ See the discussion in AM Mangu. "Xenophobia and migration in post-apartheid South Africa: Myths and realities". African Journal of Democracy \& Governance 6/1. 2019. 45-72. $<$ https://journals.co.za/docserver/fulltext/ajdg_v6_n1_a3.pdf?expires=1603797483

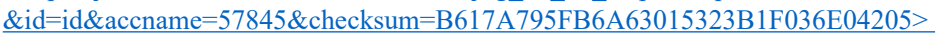
Accessed on 15 May 2021.

${ }^{66}$ See this research report for an outline of this particular problem in Africa. E Ouédraogo. "Advancing military professionalism in Africa". Research Paper No. 6. Africa Center for Strategic Studies. July 2014. $<$ https://africacenter.org/wp-content/uploads/2016/06/ ARP06EN-Advancing-Military-Professionalism-in-Africa.pdf $>$ Accessed on 15 May 2021.

${ }^{67}$ See HM Howe. Ambiguous order: Military forces in African states. London: Lynne Rienner, 2001, Chapter 2: "The roots and results of African military unprofessionalism".

${ }^{68}$ See, for example, this discussion on the professionalism of the Botswana military in D Henk. "The Botswana Defence Force: Evolution of a professional African military". African Security Studies 13/4. 2004. 85-99. doi: 10.1080/10246029.2004.9627322

${ }^{69}$ For an interesting discussion on the misuse of military resources in Africa, see P Nantulya. "Resource mismanagement a threat to security in Africa". Spotlight. African Center for Strategic Studies. 7 September 2016. $<$ https://africacenter.org/spotlight/resource-mismanagement-a-threat-to-security-in-africa/>Accessed on 15 May 2021.

${ }^{70}$ See the "Protocol relating to the establishment of the Peace and Security Council of the African Union". <http://www.peaceau.org/uploads/psc-protocol-en.pdf $>$ Accessed on 15 May 2021.

71 M Aeby. "SADC - The Southern African Arrested Development Community: Enduring challenges to peace and security in southern Africa". The Nordic Africa Institute. 2019. 37. $<$ https://www.diva-portal.org/smash/get/diva2:1351257/FULLTEXT01.pdf $>$ Accessed on 15 May 2021.

${ }^{72}$ I Liebenberg \& R Steenkamp-Fonseca. "South Africa's defence diplomacy in Africa". In I Liebenberg, D Kruijt \& S Paranjpe (eds), Defence diplomacy and national security strategy: Views from the Global South. Stellenbosch: SUN Press, 2020, 114-118.

${ }^{73} \mathrm{~F}$ Mangena. "Open border issues, crime and xenophobia in South Africa: Some ethical insights". JOCAP - Journal of Contemporary African Philosophy. May 2020. 28-42. $<$ https://www.domuni.eu/media/opress/jocap - v 5.pdf\#page $=28>$ Accessed on 15 May 2021.

${ }^{74}$ MVE Dithebe \& TT Mukhuba. "Illegal immigration and the challenge of border control in South Africa". African Renaissance 15/2. June 2018. 127-147. $<$ https://journals. co.za/docserver/fulltext/aa_afren_v15 n2 a7.pdf?expires $=1605782569 \&$ id=id\&accn $\underline{\text { ame }}=57845$ \& checksum $=2 \overline{E C C} 3805$ A063983978071D8634F463FE $>$ Accessed on 15 May 2021.

${ }^{75}$ Sullivan defines a criminal insurgency as "the mechanism of the confrontation with the state that results when relationships between organized crime and the state fall into disequilibrium". See JP Sullivan. "Criminal insurgency: Narcocultura, social banditry, and information operations". Small Wars Journal. 3 December 2012. Online Publication. $<$ https://smallwarsjournal.com/jrnl/art/criminal-insurgency-narcocultura-social-banditry-and-information-operations \#: : text $=$ Criminal $\% 20$ insurgency $\% 20$ is $\% 20$ the $\% 20$ mechanism, the $\% 20$ state $\% 20$ fall $\% 20$ into $\% 20$ disequilibrium $>$ Accessed on 15 May 2021.

${ }^{76}$ R Killebrew. "Criminal insurgency in the Americas and beyond”. Prism 2/3. January 2013. 49. $<$ https://cco.ndu.edu/Portals/96/Documents/prism/prism_2-3/Prism_33-52_Killebrew. pdf $>$ Accessed on 15 May 2021. 
${ }^{77} \mathrm{G}$ Lamb. "Police militarisation and the 'war on crime' in South Africa". Journal of Southern African Studies 44/5. 2018. 933-949. doi: 10.1080/03057070.2018.1503831

${ }^{78}$ Remarks by Helen Zille from the Democratic Alliance at a conference titled "South Africa and Africa: Prevaricating at the Precipice?" presented by the Department of Political Studies and Governance, University of the Free State, Osaka School for International Public Policy and the Southern African Centre for Collaboration in Peace and Security Studies, Bloemfontein, 10 February 2020. $<\underline{\text { https: } / / \text { twitter.com/helenzille/status/12267 }}$ 92928804298752?lang=en>Accessed on 15 May 2021.

79 "Hope and fear in South Africa". Strategic Comments 5/4. 1999. 1-2. doi: $10.1080 / 1356788990544$

${ }^{80} \mathrm{~J}$ van Wyk. "The executive and the military in South Africa during the Zuma presidency". In R Steven, C Radomir \& A Sergio (eds), Guns \& roses: Comparative civil-military relations in the changing security environment. London: Palgrave Macmillan, 2019, $97-116$.

${ }^{81}$ The resent use of an SAAF plane for party-political purposes for a meeting with Zimbabwe is a textbook example in this regard. See C du Plessis. "ANC says it will repay Zim flight money". Daily Maverick. 15 September 2020. $<$ https://www.dailymaverick.co.za/article/2020-09-15-anc-says-it-will-repay-zim-flight-money/> Accessed on 15 May 2021.

${ }^{82} \mathrm{O}$ van Heerden. "A cautionary tale of power and influence - or simply a monumental breach in our national security?” Daily Maverick. 2 February 2021. $<$ https://www.dailymaverick.co.za/opinionista/2021-02-02-a-cautionary-tale-of-power-and-influence-or-simplya-monumental-breach-in-our-national-security/> Accessed on 15 May 2021.

${ }^{83}$ defenceWeb. "Shoke stays on as Chief SANDF". 29 October 2019. $<$ https://www.defenceweb. co.za/featured/shoke-stays-on-as-chief-sandf/> Accessed on 15 May 2021.

${ }^{84}$ For an in-depth analysis of civil-military relations in South Africa, see the chapter on civil-military relations in L Heinecken. South Africa's post-apartheid military: Lost in transition and transformation. Cape Town: UCT Press, 2019, 62-78. $<\underline{\text { https://www. }}$ amazon.com/South-Africas-Post-Apartheid-Military-Transformation/dp/3030337332> Accessed on 15 May 2021.

${ }^{85}$ defenceWeb. "CSANDF non-appearance at Parliament 'disrespectful'”. 19 June 2020. $<$ https:// www.defenceweb.co.za/sa-defence/sa-defence-sa-defence/csandf-non-appearance-at-parliament-disrespectful/ $>$ Accessed on 15 May 2021.

${ }^{86} \mathrm{~J}$ Gerber. "'You're not our clients. We take instructions from the president' - SANDF to MPs amid brutality claims". News24. 23 Apr 2020. $<\underline{\text { https://www.news24.com/news24/ }}$ SouthAfrica/News/military-rattles-sabres-amid-complaints-of-heavy-handedness-20200422> Accessed on 18 May 2021. Also see defenceWeb, "Parliamentary committee takes "strong exception" to CSANDF absence". 22nd Jun 2020. $<\underline{\text { https:// }}$ www.defenceweb.co.za/featured/parliamentary-committee-takes-strong-exception-to-csandf-absence/> Accessed 18 May 2021.

${ }^{87}$ W Janse van Rensburg. "Twenty years of democracy: An analysis of parliamentary oversight of the military in South Africa since 1994". PhD dissertation. Stellenbosch University, 2019. < $<$ https://scholar.sun.ac.za/handle/10019.1/105774> Accessed on 15 May 2021.

${ }^{88}$ L Nathan. "Who's keeping an eye on South Africa's spies? Nobody, and that's the problem". The Conversation. 25 September 2017. $<$ https://theconversation.com/whos-keepingan-eye-on-south-africas-spies-nobody-and-thats-the-problem-84239>Accessed on 15 May 2021.

${ }^{89}$ See P Alexander. "Marikana, turning point in South African history". Review of African Political Economy 40/138. 2013. 605-619. doi: 10.1080/03056244.2013.860893 
${ }^{90}$ This was clearly the case in the killing of a senior police officer in Cape Town recently. See N McCain \& J Evans. "Charl Kinnear murder: Police must explain why armed protection of anti-gang cop was withdrawn - expert". News24. 21 September 2020. $<\underline{\text { https:// }}$ www.news24.com/news24/southafrica/news/charl-kinnear-murder-police-must-explain-why-armed-protection-of-anti-gang-cop-was-withdrawn-expert-20200921> Accessed on 15 May 2021.

${ }^{91}$ For an in-depth analysis of this problem in the SANDF, see Chapter 2 of Heinecken op. cit., pp. 21-41.

92 "South Africa after Zuma". Strategic Comments 24/4. 2018. i-ii. doi: $\underline{10.1080 / 13567888.2018 .1470741}$

${ }_{93}^{93}$ Congress of South African Trade Unions.

${ }^{94}$ South African Communist Party.

${ }^{95} \mathrm{O}$ van Heerden. "We need a new social compact in South Africa — and trade unions must join the party". Daily Maverick. 27 January 2021. $<\underline{\text { https://www.dailymaverick.co.za/opin- }}$ ionista/2021-01-27-we-need-a-new-social-compact-in-south-africa-and-trade-unionsmust-join-the-party/> Accessed on 15 May 2021.

${ }^{96}$ T Madia. "SANDF warns against members getting involved in ANC affairs". News 24. 23 September 2020. <https://www.news24.com/news24/southafrica/news/sandfwarns-against-members-getting-involved-in-anc-affairs-20200923?fbclid=IwAR0zJsp9 aQ598qJ60eX QBpUmLELzWgMSVMaKXG7ejsfQs09 w2rL8ej-Y> Accessed on 15 May 2021; T Madia. "SANDF cadres' assembly to discuss state of ANC is a 'recipe for a coup' - former MK members". News24. 24 September 2020. $<$ https://www.news24.com/news24/southafrica/news/sandf-cadres-assembly-to-discuss-state-of-anc-is-a-recipe-for-a-coup-former-mk-members-20200924? fbclid=IwAR2qP7YEKhb2FNfwupL8fg4PgZlPW1FPup-1YjO2CCjuFODn8R9RuND1c3M> Accessed on 15 May 2021; Z Matiwane. "Former intelligence chief urges troops to intervene in ANC". Sunday Times. 27 September 2020. $<$ https://www.timeslive. co.za/sunday-times/news/2020-09-27-former-intelligence-chief-urges-troops-to-intervene-in-anc/?fbclid=IwAR3VO163u1wAVaezcZo3yZmYTizJu1kFUUL0SxQ UUt5gIzam5a41GYHgg4> Accessed on 15 May 2021; T Venter. "Hoe nou gemaak met die weermag?" Netwerk24. 28 September 2020. $<$ https://www.netwerk24. com/Stemme/Menings/hoe-nou-gemaak-met-die-weermag-20200927?fbclid=IwAR2kRNTNpXSOY5FKgcU IIdtYNnMCf2-oKN3IB7HdO3qGfPRlmAceI9uihs> Accessed on 15 May 2021. 